Gut, 1981, 22, 623-627

\title{
Protein synthesis by cultured jejunal mucosa from control subjects and patients with coeliac disease
}

\author{
P E JONES, * C L L'HIRONDEL, $\dagger$ AND T J PETERS \\ From the Department of Medicine, Royal Postgraduate Medical School, London* $\dagger$ and \\ Division of Clinical Cell Biology, MRC Clinical Research Centre, Harrow, Middlesex $\ddagger$
}

SUMMARY Jejunal biopsies from patients with coeliac disease and from controls were cultured in vitro for 24 hours with ${ }^{14} \mathrm{C}$-labelled leucine. The net rate of protein synthesis was found to be linear over 24 hours for mucosa from control subjects and patients with coeliac disease. Protein synthesis by mucosa from untreated coeliac patients was significantly greater than by control mucosa. Protein synthesis by treated gluten-sensitive coeliac mucosa was significantly less than that by untreated coeliac mucosa and did not differ from control mucosa. Protein synthesis by treated non-responsive coeliac mucosa was significantly less than untreated coeliac mucosa but greater than control mucosa. The differences in protein synthesis could not be accounted for by differences in the size of the enterocyte leucine pool. Analytical subcellular fractionation of cultured jejunal mucosa showed that most of the protein synthesised in vitro was found in the cytosol and endoplasmic reticulum-brush border fractions of the enterocyte.

In coeliac disease the enterocytes show marked structural abnormalities on both light and electron microscopy. ${ }^{1}$ Little is known, however, of enterocyte function in coeliac mucosa and we have therefore developed a reliable in vitro organ culture technique for small intestine ${ }^{2}$ in order to investigate functional abnormalities in intestinal mucosa from patients with coeliac disease. Protein synthesis was measured in mucosa from control subjects and patients with coeliac disease both before and after treatment by gluten withdrawal in order to define the cytopathology of the disease and to investigate further enterocyte function in patients unresponsive to treatment with a glutenfree diet.

\section{Methods}

P A T I E N T S

Four groups of patients were studied; patients with untreated coeliac disease (12), patients with

\footnotetext{
* Present address: University Department of Gastroenterology, Manchester Royal Infirmary, Oxford Road, Manchester M13 9WL.

$\dagger$ Present address: Departement de gastroenterologie, Centre Hospitalier Universitaire, 14040, Caen Cedex, France.

¥Address for correspondence: $\mathrm{Dr} T \mathrm{~T}$ Peters, Division of Clinical Cell Biology, MRC Clinical Research Centre, Watford Road, Harrow, Middlesex HA1 3UJ, England.

Received for publication 10 February 1981
}

treated gluten-sensitive coeliac disease (13), and patients unresponsive to treatment with a gluten free diet (7). ${ }^{34}$ The clinical details of the patients with malabsorption and a flat mucosa unresponsive to a gluten free diet have been described in detail elsewhere. ${ }^{5}$ At the time of study, the patients had been on a strict gluten free diet for up to five years and were not receiving zinc supplements or on corticosteroid treatment. Patients undergoing investigation for suspected gastrointestinal disorders, whose jejunal morphology was normal, served as controls (11).

Seven patients with untreated coeliac disease were studied before and after successful treatment by gluten-withdrawal. Jejunal biopsies were obtained with a Watson-Crosby capsule $10 \mathrm{~cm}$ distal to the ligament of Treitz. The biopsies were divided into pieces for routine histology and in vitro organ culture. Portions of the biopsies were cultured in vitro for 24 hours by the method described previously. ${ }^{2}$ Net protein synthesis was measured by culturing mucosa with $2 \mu \mathrm{Ci} \mathrm{U}\left[{ }^{14} \mathrm{C}\right]$ leucine $(50 \mu \mathrm{Ci} / \mathrm{mg}$, The Radiochemical Centre, Amersham) added to the culture medium. At the end of the culture period the tissue was homogenised and protein precipitated from the tissue homogenate and culture medium with $10 \% \mathrm{w} / \mathrm{v}$ trichloracetic acid and washed with ethanol and with methanol: chloroform $(1: 1, \mathrm{v} / \mathrm{v})$, dried and 
counted in a Beckman LS250 scintillation counter in toluene containing $5 \mathrm{~g} / 1 \mathrm{PPO}$ and $0.4 \mathrm{~g} / 1$ dimethyl POPOP. The filters were washed with $10 \mathrm{mmol} / 1$ leucine before use. DNA was measured in tissue and medium by the method of Le Pecq and Paoletti ${ }^{6}$ with calf thymus DNA as standard.

Leucine content of the enterocytes was measured by automatic amino acid analysis. Jejunal mucosa was homogenised in $1 \mathrm{ml}$ distilled water and an aliquot taken for DNA assay. The homogenate was centrifuged at $100000 \mathrm{~g}$ for one hour in an $8 \times 10 \mathrm{ml}$ angle head rotor. As a tracer, $1 \mu{ }^{14} \mathrm{C}$ leucine $(50 \mu \mathrm{Ci} / \mathrm{mg})$ was added to the supernatant, which was loaded onto a Biogel P2 column $(25 \mathrm{~cm}$ $\times 1 \mathrm{~cm}$ ), equilibrated with $0 \cdot 1 \mathrm{~mol} / 1$ acetic acid. Fractions containing radiolabel were pooled, lyophilised, and assayed for leucine content.

Analytical subcellular fractionation of jejunal biopsies was carried out, before and after culture, as described previously. ${ }^{7}$ The experiments described in this paper had been approved by the local ethical committee. Statistical analysis of results was carried out with the Wilcoxon rank sum test.

\section{Results}

In vitro incorporation of ${ }^{14} \mathrm{C}$-leucine into TCAprecipitable protein was found to be linear during 24 hour culture both for normal and untreated coeliac mucosa (Fig. 1). Protein synthesis (Fig. 2)

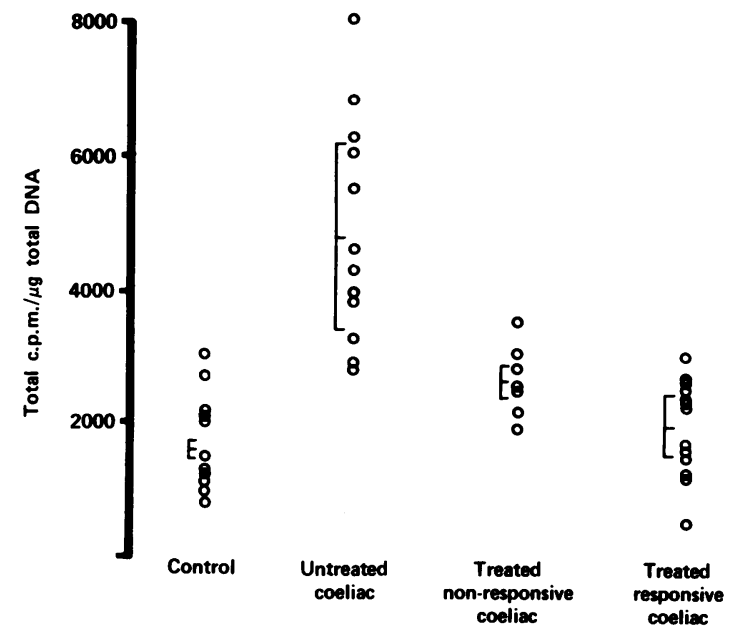

Fig. 2 Incorporation of ${ }^{14} \mathrm{C}$-leucine into protein by intestinal mucosa from four patient groups after 24 hour culture. Results show mean $\pm S E$.

by untreated coeliac mucosa, $4480 \mathrm{cpm} / \mu \mathrm{g}$ DNA/ $24 \mathrm{~h}(95 \%$ confidence limits 3270-6270) was significantly greater than by normal mucosa $1500 \mathrm{cpm} / \mu \mathrm{g}$ DNA $/ 24 \mathrm{~h}(95 \%$ confidence limits 1000-2700, $\mathbf{P}<0.01$ ). After successful treatment, protein synthesis by regenerated coeliac mucosa $(2210-2570 \mathrm{cpm} / \mu \mathrm{g}$ DNA/24 h) was less than by

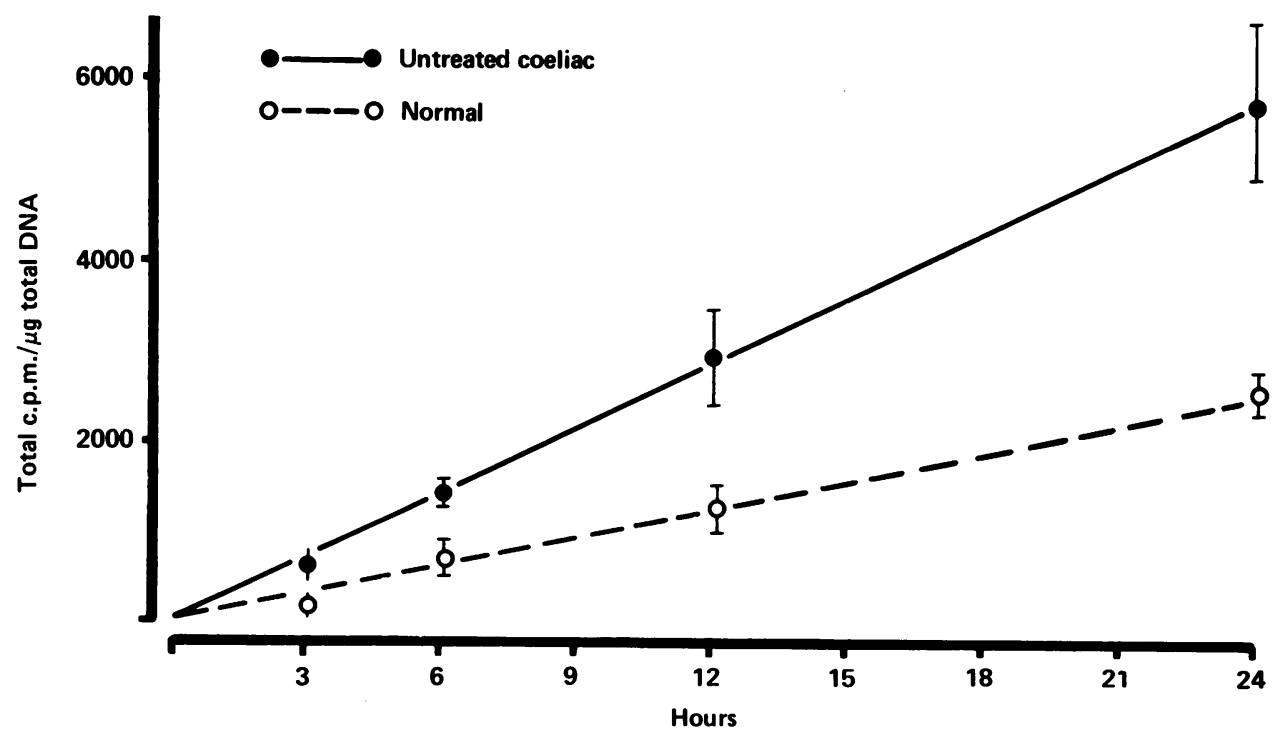

Fig. 1 Incorporation of ${ }^{14} \mathrm{C}$-leucine into protein by untreated coeliac and normal mucosa during 24 hour culture. Results show mean $\pm S E$. 
untreated coeliac mucosa $(P<0.01)$ and not significantly different from normal mucosa. In contrast, protein synthesis by non-responsive coeliac mucosa, $2570 \mathrm{cpm} / \mu \mathrm{g}$ DNA/24 h $(95 \%$ confidence limits 1990-3450) was significantly greater than normal mucosa $(P<0.05)$.

Figure 3 shows sequential measurements of protein synthesis in seven patients before and after successful treatment by gluten withdrawal. All patients showed a decrease in protein synthetic activity: mean synthetic rate before and after treatment 4970 and $2130 \mathrm{cpm} / \mu \mathrm{g} \mathrm{DNA} / 24 \mathrm{~h}$, respectively. Tissue : medium ratio of labelled protein after 24 hour culture was, for normal mucosa $6.5 \pm 1.6$ (mean $\pm 1, S D$ ), for untreated coeliac mucosa $6 \cdot 2 \pm 1 \cdot 6$, and for treated gluten-sensitive coeliac mucosa $6 \cdot 0 \pm 2 \cdot 2$ : these differences are not significant.

In six patients, the leucine content of the jejunal biopsies was measured and values obtained were: normal mucosa $0.228 \mathrm{nmol}$ leucine $/ \mu \mathrm{g}$ DNA

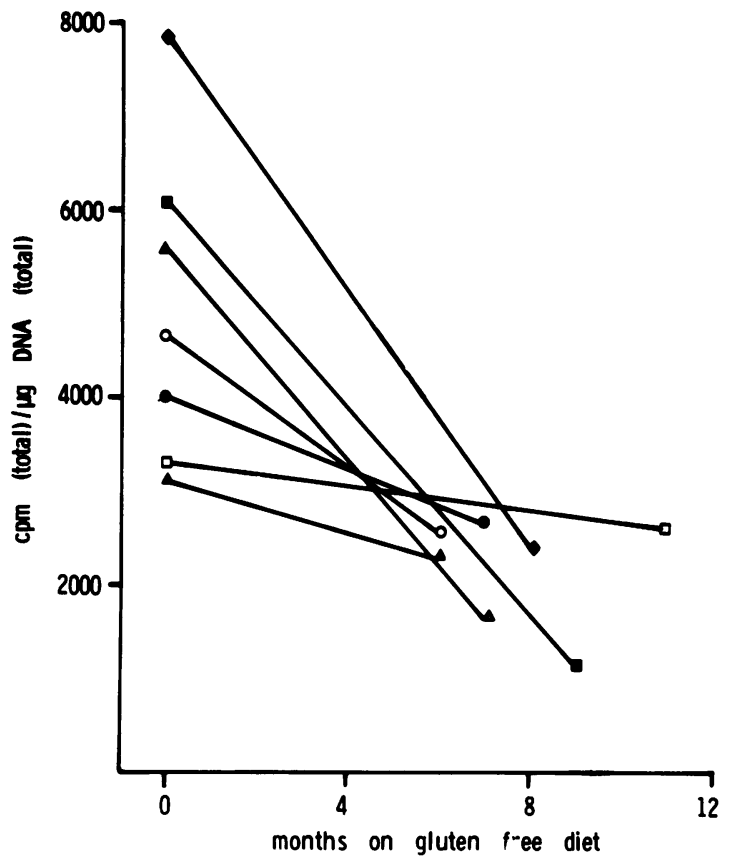

Fig. 3 In vitro protein synthesis, before, and after successful treatment by gluten withdrawal, by intestinal mucosa from seven patients with coeliac disease. Patient's initials and jejunal morphology before and after treatment: Pva=partial villous atrophy. $\backslash D$ flat : pva. $\square M$ flat : pva. $\triangle B T$ flat : nva. $\bigcirc V C$ flat : pva. $\bullet B$ flat: pva. $\square D T$ flat : pva. $\triangle M C$ pva: normal. (three patients), treated responsive coeliac mucos $0.346 \mathrm{nmol}$ leucine/ $\mu \mathrm{g}$ DNA (one patient), untreated coeliac mucosa $0.374 \mathrm{nmol}$ leucine $/ \mu \mathrm{g}$ DNA (two patients).

Analytical subcellular fractionation (Fig. 4) of control mucosa cultured in the presence of ${ }^{14} \mathrm{C}$ leucine shows most of the labelled protein in the soluble fractions with an additional peak at modal density $1 \cdot 16$. Similar studies (not shown) with cultured treated gluten-sensitive coeliac mucosa and treated non-responsive coeliac mucosa also showed a similar sucrose gradient distribution of radio-labelled protein. The peak at density 1.16 corresponds to the endoplasmic reticulum (alkaline $\alpha$-glucosidase) and brush border (alkaline phosphatase) marker enzymes.

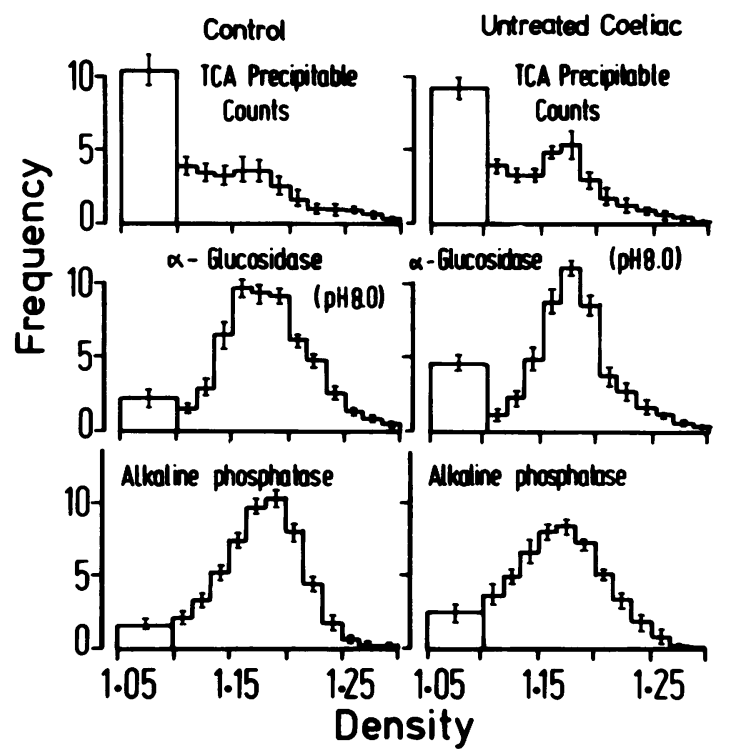

Fig. 4 Isopycnic centrifugation of post-nuclear supernatant from normal and untreated coeliac jejunal biopsies after 24 hour culture with ${ }^{14} \mathrm{C}$-leucine. Graphs show frequency-density histograms for marker enzymes and TCA-precipitable labelled proteins. Results show mean $\pm S D$ distributions. Recoveries range from 87 to $104 \%$.

\section{Discussion}

These data show that, during 24 hour culture, protein synthesis by mucosa from both control sub- 
jects and patients with coeliac disease is linear with respect to time. Most of this net protein synthesis takes place in the enterocyte, as has been shown by autoradiographic studies of cultured mucosa where the enterocytes are seen to be densely labelled, while the cells of the lamina propria contain little label. ${ }^{2}$ Similar results were obtained by Hauri and colleagues ${ }^{8}$ who used a different organ culture technique. Untreated coeliac mucosa shows a greater rate of protein synthesis than control mucosa and this may reflect the immaturity of the enterocytes lining the villous. This increase in total protein synthesis contrasts with the decrease in alkaline phosphatase synthesis shown by untreated coeliac mucosa in culture. $^{9}$

Treated gluten-sensitive coeliac mucosa shows a protein synthetic rate which is less than untreated coeliac mucosa and not significantly different from control mucosa; this presumably reflects the greater maturity of the enterocytes lining the regenerated villi. The sequential studies in seven patients confirm the fall in the rate of protein synthesis which occurs when gluten withdrawal results in villous regeneration. Coeliac mucosa, unresponsive to treatment with a gluten free diet, shows a protein synthetic rate greater than normal mucosa but less than untreated coeliac mucosa. In coeliac disease, unresponsive to treatment with a gluten free diet, the jejunal morphology shows subtotal villous atrophy, and, while there is much discussion concerning the nature of this disorder, it does appear to be a distinct entity. The marked differences in protein synthesis between the untreated coeliac and unresponsive coeliac groups of patients, both with subtotal villous atrophy, is additional evidence supporting this classification.

The tissue: medium ratio of labelled protein after culture period (range 6.0-6.5) is in keeping with the findings of Hauri and colleagues $^{8}$ who also demonstrated an increase in labelled protein in the culture medium. This protein may be secreted by the. enterocyte ${ }^{10}$ into the culture medium, as well as deriving from epithelial cells which have been shed into the medium. In addition, newly synthesised immunoglobulins are also found in the medium. ${ }^{11}$

It is unlikely that the increase in incorporation of ${ }^{14} \mathrm{C}$-leucine into protein shown by untreated coeliac mucosa is a reflection of a decreased enterocyte leucine pool. In fact, amino acid analysis shows that the free leucine in the untreated coeliac mucosa is slightly higher than control mucosa. Similarly, the fall in protein syn- thesis by treated gluten-sensitive mucosa cannot be accounted for by differences in leucine pools.

From the data obtained on analytical subcellular fractionation, it appears that the protein synthesised in vitro is present mainly in the soluble part of the cytoplasm and, to a lesser extent, attached to the endoplasmic reticulum and brush border of the cultured enterocyte. The proportions are similar in all patient groups. In individual experiments it is possible to distinguish between endoplasmic reticulum and brush border components: labelled protein appears to be mainly associated with the endoplasmic reticulum. It is therefore of interest that autoradiographic studies show that the brush border is quite heavily labelled after culture with ${ }^{14} \mathrm{C}$-leucine ${ }^{2}$ and the explanation for this paradox is uncertain. It may reflect detachment of adsorbed soluble proteins from the brush border by the subcellular fractionation procedure.

We are grateful to Dr M Szelke for the leucine estimations, to $\mathrm{Mr}$ Peter White for expert technical assistance, and to Ms Rosamund Greensted for typing the manuscript.

\section{References}

${ }^{1}$ Booth CC. The enterocyte in coeliac disease. $\mathrm{Br}$ Med J 1970; 2:725-31.

${ }^{2}$ L'Hirondel C, Doe WF, Peters TJ. Biochemical and morphological studies on human jejunal mucosa maintained in culture. Clin Sci Mol Med 1976; 50: 425-8.

3Jones PE, Peters TJ. DNA synthesis by jejunal mucosa in responsive and non-responsive coeliac disease. Br Med J 1977; 1:1130-1.

${ }^{4}$ Peters TJ, Jones PE, Jenkins WJ, Wells G. Analytical subcellular fractionation of jejunal biopsy specimens: enzyme activities, organelle pathology and response to corticosteroids in patients with nonresponsive coeliac disease. Clin Sci Mol Med 1978; 55:293-300.

"Jones PE, Peters TJ. Oral zinc supplements in nonresponsive coeliac disease. Effect on jejunal morphology, enterocyte production and brush border disaccharidase activities. Gut 1981; 22:194-8.

'Le Pecq JB, Paoletti C. A new fluorimetric method for RNA and DNA determination. Anal Biochem 1966; 17:100-5.

${ }^{7}$ Peters TJ. Analytical subcellular fractionation of jejunal biopsy specimens: methodology and characterisation of organelles in normal tissue. Clin Sci Mol Med 1976; 51:557-74.

${ }^{8}$ Hauri HP, Kedinger M, Haffen K, Grenier JF, Hadorn B. Organ culture of human duodenum and jejunum. Biol Gastroenterol (Paris) 1975; 8:307-19. 
${ }^{9}$ Jones PE, L'Hirondel C. Peters TJ. Alkaline phosphatase synthesis and properties of subcellular organelles during in vitro culture of jejunal biopsies from control subjects and patients with coeliac disease. Gut 1981; in press.

10 Mitchell JD, Mitchell J, Peters TJ. Enzyme changes
11 Loeb PM, Strober W, Falchuk ZM, Laster L Incorporation of $\mathrm{L}$ leucine-1.1 $\mathrm{C}$ into immunoglobulins by jejunal biopsies of patients with coeliac sprue and other gastrointestinal diseases. J Clin Invest 1971; 50:559-69. 